\title{
Kroatien lider under \\ lidenhedens forbandelse
}

\section{Richard Swartz}

\section{Kroatien befinder sig stadig i et limbo mellem EU og et ubestemmeligt alternativ, om hvilket man kun ved med sikkerhed, at det ikke har nogen fremtid}

Kroatiens nye præsident spiller klaver. Måske ikke som Ignacz gjorde en gang, men sikkert bedre end Edward Heath eller Helmuth Schmidt. Ivo Josipovic er juraprofessor, men desuden uddannet på konservatoriet i Zagreb, og skulle han få tid tilovers i præsidentpaladset, har han tænkt sig at færdiggøre en opera om John Lennon. Josipovic er godt halvtreds og noget af en svigermors drøm: høflig og mildt lavmælt uden at blive harmløs, en type som man kan finde i de fleste større europæiske byer, og som til enhver tid vil hjælpe gamle damer over gaden. Men politiker? Josipovic har aldrig været politiker, kun 'skolelærer', som Milan Bandic kalder ham.

Om denne modstander ved præsidentvalget kan der ikke siges meget mere, end at Bandic er en sand bal- kansk politiker og vel næppe ved, hvad et klaver er. Bandic er fra Hercegovina, den del af staten BosnienHercegovina, som kroatiske indbyggere plejer at opfatte som en slags kroatisk Piemonte. For mange af dem er det stadig svært at forstå, at kvinder og langhårede ynglinge med kun dun på overlæben skal kunne bestemme, hvem der har magten, ved med nogle års mellemrum at stoppe en lap papir i en valgurne. Under mere normale omstændigheder ville måske også vælgerne $\mathrm{i}$ det egentlige Kroatien have været af samme mening. Men tiderne er ikke normale. Kroaterne er trætte af politik. Med politik mener de tomme løfter, intriger og korruption. Frem for alt netop den daglige, omfattende korruption. Derfor har kroaterne valgt Ivo Josipovic til præsident, en 
professor som i stedet for politik og skandaler har befattet sig med at øve skalaer på klaveret.

Kroatien er et meget lille europæisk land, hvor alle kender alle, eller i det mindste tror de gør det. Næsten hver lørdag ved middagstid kan man møde alle, som er noget i Zagreb, mellem caféen Charlie og Cvetni Trg (Blomstertorvet). Dukker man ikke op der, regnes man ikke for noget. Franjo Tudjman, den moderne kroatiske stats fader, ville gøre landet større ved at medregne territorialfarvandet. Kroatien har en lang og meget smuk kyst. Desuden mente han, at Kroatien 'regionalt' var en stormagt uden at gøre det helt klart, hvordan denne region så ud. Thi Balkan var et ord, den afdøde landsfader aldrig tog i sin mund, når han udtalte sig om sit katolske, centraleuropæiske Kroatien.

Samtidig er Kroatien dog tilstrækkelig stort til at have overlevet $\mathrm{i}$ mere end tusinde år. Man har med held værget sig mod okkupanter, mod magyarisering, fortyskning gennem sprog og kultur og mod serbisk dominans. Men alligevel er Kroatien så lille, at det ikke rigtig har været nok til en fungerende stat. Ante Pavelics fascistiske Kroatien var et tysk lydrige, og dagens Kroatien befinder sig stadig i et limbo mellem EU og et ubestemmeligt alternativ, om hvilket man med sikkerhed kun ved, at det ikke har nogen fremtid. Og Kroatiens største aktiv i forhold til EU er måske, at det er så lille.

\section{Lidenhedens forbandelse}

Allerede Krleza havde i sin tid problemer med størrelsen. Miroslav Krleza (1893-1981) er landets største forfatter og byttede som kroatisk patriot det store (Habsburg) med det lille (Jugoslavien). I den senere del af sit liv kan han have ændret opfattelse. Til det allerbedste i hans værk hører det, han har skrevet om netop indelukkethed, det trøstesløse og smålige i provinsen, om selve lidenhedens forbandelse. Engang i begyndelsen af halvfjerdserne ville jeg opsøge ham. Alle sagde, at det var umuligt. Krleza var efter sigende en alt for optaget mand. Men det viste sig at være muligt. I telefonen svarede mesteren selv: "Kom til en kop kaffe". Den eftermiddag sad vi sammen i flere timer, og Krleza ville ikke lade mig gå, men næppe på grund af min lysende konversation. "Kom snart tilbage", sagde han til afsked, "ingen besøger mig længere". Han pegede på telefonen. Det var sandt. Ikke en eneste gang under mit besøg havde den ringet. "Det er så sjældent efterhånden, at jeg får besøg fra verden".

Inden for lågen ligger sneen dyb. Her er der ingen, der rydder. Min ven professoren bor alene i den store villa, og med sine 95 år er han ikke meget yngre end sit eget hus. "Jugoslavien var naturligvis større", siger han efter at have budt på nogle seje kager, som er tilovers efter julen, "og derfor en skole for os gan- 
ske primitive mennesker i denne del af Europa. Vi måtte lære at leve sammen med folk, vi aldrig havde villet vide noget om. Fra fjender blev de halvvejs bekendte. Desuden havde vi dengang altid nogen at give skylden. Slovenerne? Et ubetydeligt folk, som kun tænker på sig selv. En ny politisk skandale med en serber i spidsen? Men enhver ved da, hvordan det går med serbere! På den måde var Jugoslavien både skole og sikkerhedsventil. Nu har vi altså vor egen kroatiske stat. Til venstre og højre, hvor man end ser, er der kun kroater. Her er blevet for trangt for os. Og hvem skal vi nu give skylden? Eller skal vi måske begynde at tage ansvar for de problemer, vi selv laver? Men dertil behøver et folk mindst hundrede år."

\section{Som skrift i vand}

Udenfor sner det igen. Min ven professoren er ikke sikker på, at dagens kroater er mindre deprimerede, end de var som kroater i Jugoslavien. Det er egentlig mærkeligt i betragtning af, at de nu har fået den stat, de længtes efter. Forklare det kan han ikke. En del trøster sig med flasken, andre går i kirke. En og anden sidder hjemme med hovedet $\mathrm{i}$ hænderne. Professorens eget hoved er i bedre stand end benene. Alligevel insisterer han på at følge mig til døren. Det er den gamle habsburgske skole: faderen var 'kejserlig \& kongelig' general, og i barndoms- hjemmet gik hans ungarske officerskammerater ind og ud. Omtrent hundrede år senere beundrer sønnen stadig den ungarske kultur, som har efterladt sig så få spor i en verden, den beherskede i så lang tid. "Som skrift i vand", siger han og ryster undrende på hovedet. Så mærkværdigt finder han dette faktum, at det burde blive samtaleemne ved mit næste besøg.

"Nej," siger Slavko Goldstein, "det er ikke sandt, at ingen besøgte Krleza. Tro mig, jeg var der ofte. Men han var følsom for stemninger og følte sig vel ensom den dag, De var hos ham." Slavko Goldstein er i en og samme person forlægger, forfatter, politisk kommentator og en slags halvofficiel historisk samvittighed, når det gælder kroatiske forhold. Bag ham på væggen hænger nationaldigteren i glas og ramme. Krleza ligner en mæt og temmelig træt løve, og Slavko Goldstein neden under ham bag skrivebordet ser uendelig meget yngre ud end sine godt firs år.

Han fortæller mig, at Krleza plejede at klage over søvnløshed og manisk skrivetrang "til den kroatiske litteraturs gavn". Men at Ivo Andric fik nobelprisen i litteratur, og at verden ikke rigtig tog notits af hans eget forfatterskab generede Krleza. Dog vidste Krleza, at den skæbne er typisk for den, der tilhører en lille nation. At være afhængig af et sådant folks modersmål i sit virke fører næsten altid til skuffelser. "Ja," siger 
Slavko Goldstein, "det kongelige Jugoslavien blev en skuffelse for Krleza. Også det kommunistiske, selv om han og Tito altid kom godt ud af det med hinanden. Skuffelse fulgte på skuffelse, og hans verden skrumpede, indtil den fandtes et andet sted."

Bagefter siger han med et ironisk smil, at Kroatien i dag er en "stolt nation", og at landets politikere kan lide at sige, at de ikke har tænkt sig at vende tilbage til Europa krybende på deres knæ. Jeg spekulerer på, hvad det betyder. Indeholder påstanden lige dele realisme om egen storhed og overmodig selvovervurdering? Men inden jeg har nået at spørge, er min tid udløbet. Slavko Goldstein har travlt. New York Review of Books har bedt ham skrive et essay om Kroatiens tre præsidenter: Franjo Tudjman, Stipe Mesic og Ivo Josipovic. I en by som New York, hvor kun meget få ville kunne finde Kroatien på kortet, kan en kroatisk intellektuel næppe opleve en større ære.

"Mine tre præsidenter", siger Slavko Goldstein med et lille fornøjet smil. Naturligvis kender en person som Goldstein dem alle. Større end som så er Kroatien ikke.

\section{Europæisk bananrepublik}

Ivo Sanader var premierminister og partiformand i HDZ, statsgrundlæggeren Tudjmans gamle parti, inden han pludselig gik af i sensommeren sidste år. Da havde han stået i spid- sen for landet i næsten seks år. Som årsag til sin afgang angav han familieforhold. Ingen troede ham da, og ingen tror ham i dag, godt et halvt år senere. I januar i år blev han smidt ud af HDZ, efter at han pludselig havde forsøgt at generobre magten.

Omkring café- og stambordene mener man at vide, hvad Sanader ikke har kunnet forklare: nogen eller nogle truede med at afsløre hans konti med sorte penge i udlandet. Sanader skulle have været overordentlig modtagelig for bestikkelse, i årevis have ladet sig betale rundeligt for diverse tjenester, han som premierminister kunne tilbyde. Det skulle være de sande 'familieforhold'. Og afsløret blev han naturligvis i udlandet, for i Kroatien er jo alle politikere korrupte og dækker over hinanden. Hvorfor skulle de pludselig gå i kødet på en af deres egne? Og på en som af selvopholdelsesdrift sikkert havde samlet sig et og andet kompromitterende også om dem? Omring stam- og cafébordene mener man derfor også at vide, at det var Washington eller Angela Merkel, som tvang Sanader til at gå.

Thi Kroatien er selvfølgelig en europæisk bananrepublik. Sker der noget her, er det kun fordi nogen i omverdenen har besluttet, at noget skal ske. For de allerfleste kroater er korruptionen samtidig en slags fiktion. Den findes på tv eller $\mathrm{i}$ avisen. Det bidrager til det fiktive, at enhver offentlig person, som beskyldes for 
korruption, vredt afviser beskyldningen som absurd eller som en fornærmelse. Derefter plejer der at blive stille, så strategien med at benægte alt må anses som vellykket. Det ser endnu ikke ud til at hjælpe, at regeringen de seneste måneder har lovet kamp mod al korruption og har slæbt også ministre for retten.

I årevis gravede tidsskriftet Feral Tribune krigsforbrydelser og korruptionsskandaler frem. Om Sanadersagen skrev bladet detaljeret allerede i 2003. Feral Tribune var ikke bare mere opposition end nogen $i$ parlamentet, men også en påmindelse om, hvad journalistik egentlig handler om i et land, hvor meninger ofte træder i stedet for fakta.

Men intet skete. Ferals afsløringer blev tiet ihjel. Medarbejdere modtog mordtrusler og tidsskriftet blev slæbt for retten. Forrige år gik bladet i graven, diskret men systematisk kvalt økonomisk af hvad man kun let overdrevet kunne kalde det kroatiske establishment. Den store korruption forbliver fiktion. Den antager bare skikkelse som vage rygter, formodninger, tal med utydelige konturer, men med mange nuller. Korruptionen er noget for politikernes hemmelige bankkonti, ikke for almindelige mennesker.

\section{Kun mafiaen har råd}

Sammen med en ven går jeg på loppemarkedet på Britanac og bagefter ud for at købe ind til weekenden. På hylderne i dette bedre minimarked står kroatisk vin i rækker, nogle virkelig af bedste internationale kvalitet, men til priser, som gør det umuligt at eksportere dem. Det samme kan siges at gælde for loppemarkedet. Her og der er der noget fra tiden under Habsburg, glas eller nips, som koster mindre end det halve på loppemarkedet i Wien.

$\mathrm{Og}$ så drejer det sig alligevel om det samme sammenbrudte rige. Gode og dyre vine er her en kilde til national stolthed. Men hvem kan egentlig købe dem? Til østrigske eller svenske priser i et land, hvor man tjener en brøkdel. Her er det kun billigt at købe brød og kartofler. De fine vine er til for doktoren, siger min ven. Skal du på sygehuset, tager du sådan en flaske med. Hos os har kun mafiaen og lægerne råd til at drikke den slags vine.

Zagrebs bymuseum er næsten tomt. Det er en vinterdag med strålende solskin. En energisk guide har samlet en håndfuld besøgende, solen skinner ind gennem de få vinduer og oplyser en og anden montre. Fortiden klares med glans; men det er måske lettere med keltere end med senere okkupanter og overherrer. Jeg spekulerer på, om det overhovedet er muligt at skrive byens historie uden at kunne latin, tysk og ungarsk. Men tiden under Habsburg og Budapest behandles uden forstyrrende nationalistiske overtoner, sagligt og ikke uden sympati, mens byens efterkrigshistorie hur- 
tigt snuppes af. De fascistiske år under Pavelic og de ti gange flere år under Tito og kommunismen er stuvet væk i bare et enkelt rum. Det ser mere ud som usikkerhed end hensigt. Bagefter kan jeg ikke huske, om der var et eneste billede af Pavelic eller Tito.

Hele denne tid kan virke, som om den kun er optakt til nutidens kroatiske stat, som til sidst præsenteres som slutakten i et teaterstykke. Naturtro har man opbygget det rum i præsidentpaladset, som blev ramt af en granat i maj 1995. Den blev affyret af de serbiske udbrydere i Krajina under Milan Martics kommando. På museet står nogle ødelagte møbler, dækket af murbrokker og puds. Så tæt på var det, at statsgrundlæggeren Tudjman var blevet dræbt.

Denne søndagsmorgen med forår i luften er der ingen mennesker på gaden. Kun nogle blege nonner går forbi. Kroatien må være et af de sidste lande i Europa, hvor man aldrig ser en nonne med sort eller gul hudfarve, og det er ikke kun fordi tilgangen af indfødte skulle være sikret. Og Milan Martic? Han sidder i en celle et sted i Estland (efter at være dømt ved krigsforbryderdomstolen i Haag for krigsforbrydelser imod serbere. red.). Der skal han sidde i 35 år for forbrydelser mod menneskeheden.

\section{Europas triumf}

Milan Bandic tabte gudskelov præsi- dentvalget, siger man i Zagreb. I denne europæiske og urbane by opfattes det som Europas triumf over Balkan. Man er lettet. Her spøger man gerne med, at Bandic ikke taler et eneste fremmedsprog (heller ikke kroatisk ifølge hans ondeste kritikere). Men Balkan er alligevel ikke så langt borte, som man kunne ønske. Krigen i halvfemserne skal have ændret Zagrebs karakter; tilflytningen fra Hercegovina er enorm, mennesker som det indfødte Zagreb ikke har nogen høj mening om og ser som en trussel mod sin urbane kultur. Milan Bandic tabte godt nok præsidentvalget, men med hjælp af disse tilflyttede masser fra landet fortsætter han med at regere Zagreb som byens borgmester.

I krydset Ribnjak-Degenova er trafikken tung og hensynsløs på en måde, der næppe kan kaldes urban. En gammel dame bliver stående på fortovet uden at vove sig over gaden, selv da trafiklyset skifter til grønt. Jeg tager hende forsigtigt under armen. Sammen kommer vi over til den anden side og lige så overrasket som rørt siger hun tak: Her er nok ingen blevet hjulpet over gaden siden kejser Franz Josefs tid.

Richard Swartz er svensk journalist og forfatter. Han i flere årtier dakket østeuropaiske forhold journalistisk og som forfatter til blandt andet 'Room service'.

Oversat fra svensk af Klaus Carsten Pedersen. 